\title{
Analysis of Resupply of Energy for Workforce Accomplishing Long Term Damage Cleanup Duties
}

\author{
Judit MOLNÁR, ${ }^{1}$ Rita MOLNÁR, ${ }^{2}$ Gyula KÓRÓDI ${ }^{3}$
}

\begin{abstract}
There are a growing number of disasters in Hungary, and throughout the world, that have had devastating effects, and the activities related to prevention, protection and damage cleanup last for a long time. The defence activities are accomplished by professional organizations responsible for remedial actions, namely the National Directorate General for Disaster Management, Ministry of the Interior (NDGDM) and the Hungarian Defence Forces (HDF). Working for a long period of time at the site of damage cleanup works is a heavy burden and effort. Therefore, maintenance of the appropriate physical condition of the official staff intervening in disasters and carrying out demanding physical duties is essential for effective work activities. Catering, providing food and drink supply for organizations carrying out intervention is one of the basic responsibilities of the professional organizations. With the aid and application of the methods of modern food science the energy need of the human body accomplishing demanding activities can be determined by taking body weight and parameters of weather into account. In this work, we aim to analyse the impacts physical workers' bodies are exposed to. We also define and through examples present the amount, quality and form of the required nutrient and fluid intakes. Through our research, we would like to assist medical and logistic professionals responsible for catering the intervening organization.
\end{abstract}

Keywords: disaster, damage cleanup, hard physical activity, nutrient supplies

\section{Introduction}

In recent times, Hungary has faced increased number of catastrophic events, floods, the red sludge disaster when the success of the liquidation process largely depended on the physical capabilities of human resources. Although, in his previous work R. Kuti [1] studied the technical and personal conditions and planning difficulties of prolonged and complex technical rescues, he did not examine the importance of upholding resupply of energy of workforce in order to maintain the physical fitness and working ability in professional staff. Professional bodies dealing with damage cleanup tasks can face catastrophes at any time of the day, and the prevention of harmful effects can last for days, during which they are exposed to hard physical labour. We do believe that the human being is the central element of damage cleanup tasks. Thus, the question of upholding resupply of energy of workforce in order to maintain

1 Ph.D. student, Széchenyi István University, Institute for Food Sciences; e-mail: molnar.judit@sze.hu

2 Ph.D. student, Széchenyi István University, Institute for Food Sciences; e-mail: molnar.rita@sze.hu

3 Ph.D. med., National University of Public Service, Institute for Disaster Management; e-mail: korodi.gyula@ uni-nke.hu 
physical fitness and working ability is a high importance. In this paper, we intend to reveal the effects of prolonged hard physical activity on the human body as well as the body's energy needs. Since in many cases women are also involved in hard physical work, we defined the required nutrient and fluid intake for both men and women. Through this work, we aim to contribute to the more effective health protection of the intervening staff.

\section{The Effects of Physical Strain on the Human Body}

Professionals carrying out complex technical rescues and damage cleanup tasks often perform their duties amid extreme working conditions in special protective clothing. [2] Tasks that are to be carried out under extreme temperature conditions or in special protecting clothing and respirator with hazardous materials present are particularly energy intensive to the human body. [3] [4] Carrying the specialised equipment is a burden itself and the physical activity further increases the energy needs. Extended physical exercise coupled with insufficient inadequate nutrient intake can lead to the exhaustion of the human body. The first sign of this condition is the decrease of physical performance, to which the body can adjust itself by slightly altering its operation. Without energy intake or rest this condition can lead to health damage. Under extended physical exercise the main stress is on the muscular system through the adaptation of the circulatory system. During hard work the muscular system's demand for oxygen significantly increases, thus the blood flow speeds up 12 times more than when the body is at rest; at the same time, it requires 20 times more oxygen (it can be 50 times higher than normal under very intensive labour). This leads to more intensive work of the circulatory and the respiratory system. The efficiency of muscle work is relatively low, approximately $30 \%$, therefore $70 \%$ of the energy put into work is released as heat. [5] The body gets rid of this excess heat through heat dissipation. Through heat dissipation the body loses fluid that is important to be retained.

Working in summer at a relatively high average temperature the fluid loss increases, thus to support the members of the acting organization with adequate drinking water supply must be given high importance as early as the planning period. Besides the form of activity, the calorie requirements of the human body are also influenced by the weight, gender, age, outside temperature, the intellectual or the physical work as well. With the increase of the body weight the body requires more calories as maintaining a bigger body calls for more energy, and the human body burns off more calories when moving if the body was bigger. The table below shows the amount of energy needed to carry out two burdensome duties.

Table 1. Energy demand to carry out hard physical work.

(Authors' compilation on the basis of [6].)

\begin{tabular}{|l|l|}
\hline Form of work & Energy consumption of the work form $\mathbf{~ k c a l} / \mathbf{m i n}$ \\
\hline manual handling work & 7.23 \\
\hline logging & 6.87 \\
\hline
\end{tabular}

The table clearly shows that hard physical work requires substantial amount of energy. Consequently, adequate energy intake must be provided in order to protect the working body from irreversible health damage. 


\section{Specifying the Necessary Energy Supply for Hard Physical Work}

Human energy requirement can be ensured through adequate intake of calories and nutrients. The burning of different nutrients releases energy that is utilized by the human body. The three fundamental nutrients are carbohydrate ( $\mathrm{CHO}$ ), lipid (fat) and protein. Burning these substances releases energy that is displayed in the table below.

Table 2. Released energy in the human body through burning nutrients.

(Authors' compilation on the basis of [7].)

\begin{tabular}{|l|l|}
\hline Nutrient/gram & Energy released/kcal \\
\hline Carbohydrate $(\mathrm{CHO})$ & 4.1 \\
\hline Fat $(\mathrm{F})$ & 9.3 \\
\hline Protein $(\mathrm{P})$ & 4.1 \\
\hline
\end{tabular}

The daily calorie target for an average man is 2,000 kilocalories. To maintain this pattern the following nutrient distribution is recommended:

Table 3. The required amount of energy to maintain the normal function of the human body.

(Authors' compilation on the basis of [7].)

\begin{tabular}{|l|l|l|}
\hline Source of energy & Energy/\% & Required amount/gram \\
\hline Carbohydrate $(\mathrm{CHO})$ & $55-58$ & $268.29-282.92$ \\
\hline Fat $(\mathrm{F})$ & 30 & 64.51 \\
\hline Protein $(\mathrm{P})$ & $12-15$ & $58.53-73.17$ \\
\hline
\end{tabular}

These figures are based on estimated energy requirements for the average man; in the case of increased physical activity, higher energy intake is needed. The daily calorie need of a grown-up man to deliver hard physical work is between 3,000-6,000 kilocalories. The recommended daily amount of carbohydrate, protein and fat can be calculated from their required amount of energy (3,000-6,000 kcal). Please note 1 gram of carbohydrate equals to $4.1 \mathrm{kcal}$, 1 gram of fat equals to $9.3 \mathrm{kcal}$, whereas 1 gram of protein equals to $4.1 \mathrm{kcal}$, as Table 2 indicates. [7] A grown-up woman's energy need to do hard physical work is 2,000-4,000 kcal. Since women participate in hard physical work only exceptionally, these figures were gained through examining sportswomen's increased performance and the energy intake required to maintain their performance. The needed quantities are expressed as a percentage, for frequent usage it is suggested they be calculated in gram. 
J. MOLNÁR, R. MOLNÁR, GY. KÓRÓDI:: Analysis of Resupply of Energy for Workforce Accomplishing...

Table 4. Calorie intake recommendation for a grown-up man requiring 3,000-6,000 kilocalories of intake to deliver hard physical work.

(Authors' compilation on the basis of [6].)

\begin{tabular}{|l|l|l|}
\hline Source of energy & Energy/\% & Amount needed/gram \\
\hline Carbohydrate $(\mathrm{CHO})$ & 56 & $409.8-819.5$ \\
\hline Fat $(\mathrm{F})$ & 27 & $87.9-174.19$ \\
\hline Protein $(\mathrm{P})$ & 17 & $124.39-248.78$ \\
\hline
\end{tabular}

Table 5. Calorie intake recommendation for a grown-up woman requiring 2,000-4,000 kilocalories of intake to deliver hard physical work.

(Authors' compilation on the basis of [6].)

\begin{tabular}{|l|l|l|}
\hline Source of energy & Energy/\% & Amount needed/gram \\
\hline Carbohydrate $(\mathrm{CHO})$ & 56 & $273.2-546.6$ \\
\hline Fat $(\mathrm{F})$ & 27 & $58.6-116.12$ \\
\hline Protein $(\mathrm{P})$ & 17 & $82.92-165.84$ \\
\hline
\end{tabular}

The above-mentioned energy amount is better divided into five small portions so as to provide continuous nutrient intake. This way the equal loading of the digestive system - without any extreme swing - can also be achieved. The following table contains the breakdown of the energy intake through the recommended five meals a day.

Table 6. Recommendation of carbohydrate, fat and protein intake divided into five meals for a grown-up man delivering hard physical work.

(Data used on the basis of Table 4. Authors' compilation on the basis of [8].)

\begin{tabular}{|l|l|l|l|}
\hline $\begin{array}{l}\text { Percentage } \\
\text { breakdown }\end{array}$ & $\begin{array}{l}\text { Carbohydrate (CHO)/ } \\
\text { gram }\end{array}$ & Fat (F)/gram & Protein (P)/gram \\
\hline 20 & $81.96-163.9$ & $17.41-34.84$ & $24.80-49.70$ \\
\hline 10 & $40.98-81.95$ & $8.71-17.42$ & $12.44-24.87$ \\
\hline 35 & $143.43-286.82$ & $30.48-60.97$ & $43.54-87.08$ \\
\hline 10 & $40.98-81.95$ & $8.71-17.42$ & $12.40-24.80$ \\
\hline 25 & $102.45-204.87$ & $21.77-43.55$ & $31.10-62.20$ \\
\hline
\end{tabular}

Table 7. Recommendation of carbohydrate, fat and protein intake divided into five meals for a grown-up woman delivering hard physical work.

(Data used on the basis of Table 5. Authors' compilation on the basis of [8].)

\begin{tabular}{|l|l|l|l|}
\hline $\begin{array}{l}\text { Percentage } \\
\text { breakdown }\end{array}$ & $\begin{array}{l}\text { Carbohydrate (CHO)/ } \\
\text { gram }\end{array}$ & Fat (F)/gram & Protein (P)/gram \\
\hline 20 & $54.64-109.26$ & $11.6-23.22$ & $16.52-33.12$ \\
\hline 10 & $27.32-54.62$ & $5.8-11.6$ & $8.28-16.58$ \\
\hline 35 & $95.62-191.2$ & $20.32-40.64$ & $29.02-58.04$ \\
\hline 10 & $27.32-54.62$ & $5.8-11.6$ & $8.28-16.58$ \\
\hline 25 & $68.3-136.58$ & $14.5-29.02$ & $20.72-41.46$ \\
\hline
\end{tabular}


Providing the professional staff carrying out remedial actions with the amount of energy presented in the tables above is a demanding task for the body responsible for catering. During tasks when continuous work and high performance is required at tight time frame (such as filling sacks during flood control), the providing of the above-mentioned energy amount is crucial, since the decrease of the supply or inadequate distribution times will greatly affect the workers' achievement and efficiency.

\section{Factors Influencing Energy Intake}

The energy and nutrient requirements of the human body can be varied according to different patterns. Primarily, the changes are influenced by age, and there are further factors in the case of women. Consequently, the energy need of the young, the middle-aged and the elderly can be varied. It is essential for the professional staff to maintain strong physical fitness. At the same time, particular attention needs to be given to healthy diet. It is highly recommended to pay more attention to the quality supply of micro- and macro nutrients (trace elements, minerals, vitamins) over time. Energy intake is also influenced by gender, since women need less energy than men. Actual types of physical activity and environmental factors can also be influencing factors, which are subjects of research. Hard physical work that significantly alters the physical fitness and stamina increases the need for energy. Environmental factors are also needed to be taken into account regarding the dietary patterns, seeing that the body needs increased amounts of energy during the winter months. In comparison with the civil society, the defence sector is a "dangerous territory", since injuries and serious accidents are more frequent. In these instances, the average energy intake is to be increased compared to the average energy and macro nutrient demands. It is because proteins, carbohydrates and fats can be regarded as building blocks of the human body and they play a key role in the healing process like vitamins and minerals.

\section{Recommended Nutritional Intake}

Energy demand of soldiers involved in hard physical work is also between 3,000-6,000 kcal. This amount should be compiled for them during work in a varied, tasty and healthy pattern. In the past, food science aimed to maintain soldiers' fitness by providing them with a high number of calories (wrongly), and failed to pay attention to the vitamin and mineral demand of the human body. Therefore, varied dietary patterns got far too little emphasis, and a monotonous yet calorie-rich diet become common with corn beef and rusk as the main staples for soldiers.

When examining the intake possibilities of various forms of foods, not only the quantity distribution needs to be considered but it must be insured that the quality of the consumed food is the best. The insufficient intake of some macro nutrients can lead to decrease of performance, weight loss, or in the case of hard physical and mental burden, it can lead to exhaustion or illnesses. [9] That is the reason why products that are enriched with proteins, amino acids, unsaturated fatty acids, vitamins, minerals, as well as dried products are becoming more and more popular besides traditional foods. Yeast based single cell proteins with a high amount of protein content and favourably composed fatty acids are becoming the centre of food science. With their help, this addition can be used efficiently even with micro 
elements that are basic for the human body, since yeasts pile up micro elements efficiently. Packaging of various foods is not a minor issue. Resistant packaging, sufficient microbiological stability, instant packaging forms greatly contribute to the use of quality foods in the area of operation. The intake of vitamins and minerals plays an important role in maintaining health. Being excellent sources, the consumption of fresh vegetables and fruits is the easiest way to provide these nutrients. If they are not available, the consumption of dried fruits is a possible alternative. The calorie content of dried fruits is higher than the fresh ones, since during the drying process water is subtracted and the fructose content is more concentrated.

Dried meat can be another alternative. It is very popular among bodybuilders and can be available in gyms in small packings. Known as Beefy Jerky abroad it comes in $25 \mathrm{~g}$ and $50 \mathrm{~g}$ containers.

\section{Alternative Options}

Dried fruits and vegetables have been used in the army for a long time. A publication in the American Journal of Physiology appeared as early as 1919, on this topic. Dried vegetables are considered to be essential. Their nutrient value is characterised by their high digestible material content, especially carbohydrates. This group contains the vitamins and minerals that are essential for the human body, as well as proteins, organic acids and volatile oils. One of the benefits of dried vegetables and fruits is that their mass is decreased by $80-90 \%$ during the drying period and the space requirement can also be reduced by $50 \%$. In the respect of storability, these dried products can be stored for years. The above-mentioned article claims that the base of soups in the army were dried vegetables that were stored in paraffin-covered barrels for more than 50 years. This also proves that these dried products can keep their qualities. Since the availability of fresh fruits and vegetables is limited in the winter months, dried products can be good alternatives. [10]

Besides dried products, other alternatives are the Single Cell Proteins we have mentioned earlier. Supplying the human body with protein is one of the key factors regarding the quality of life and physical performance. [11] In order to insure that the amino acid kit remains intact under hard physical activity (in soldiers) protein of animal origin is needed, since the essential amino kit is defective in plants. [12] When manufacturing single sell proteins, the main focus is on the production of large cell mass that has biological advantages. As to nutrient requirements, it has a satisfying content for the human body with high protein and low saturated fat content. For the first time, single cell proteins were used in Germany and Russia during WWII. They have a wide use as therapy products. The most popular form of single cell protein is baker's yeast which is mass produced worldwide. Though single cell proteins are not used for human consumption or as food supplements yet, we can find specialised literature that discusses their possible consumption.

\section{Summary}

Members of official bodies performing complex technical rescues often have to work under extreme conditions for a prolonged period and deliver hard physical work. The efficiency of this work is determined by steady physical fitness and stamina that can only be achieved through an adequate energy supply. In our work, we have studied the factors that endanger 
the workers' health. We calculated and with the help of examples presented the quantity and pattern of the needed fluid and nutrient intake. With our research, we would like to raise interest in the topic, so we place a great emphasis on presenting the alternative solutions in the supplying soldiers who carry out hard physical work. Among these alternatives, we presented dried products and their forms of use. We also presented the single cell protein (SCP) the importance of baker's yeast protein that was used in human consumption during WWII. The reason for discussing and emphasizing these dietary alternatives is their high protein beneficial macronutrient content, as well as their concentrated vitamin and mineral content. As we considered during our research, the calculated numbers are highly varied and demand effectively utilized foods and food alternatives. With our research, we would like to contribute to the work of professionals responsible for the energy supply to human resources involved in hard physical work during technical rescues.

\section{References}

[1] KUTI R.: Komplex műszaki mentések tervezésének lehetőségei. Védelem Online, 233 (2010), 1-7. www.vedelem.hu/letoltes/anyagok/233-komplex-muszaki-mentesektervezesenek-lehetosegei.pdf (Downloaded: 145 2016)

[2] KUTI R., NAGY Á.: Weather Extremities, Challenges and Risks in Hungary. AARMS, 144 (2015), 29-306.

[3] KUTI R.: Advantages of Water Fog Use as a Fire Extinguisher. AARMS, 142 (2016), 259-264.

[4] KUTI R.: Vegyimentesítőhely kialakításának követelményei, az eljárás személyi és technikai feltételei. Védelem Katasztrófa-, Tüz- és Polgári Védelmi Szemle, XVIII 1 (2011), 26-27. http://vedelem.hu/letoltes/ujsag/v201101.pdf (Downloaded: 145 2016)

[5] HAGBERG, J. M.: Exercise, fitness, and hypertension. Champaign: Human Kinetic Press, 1998.

[6] RODLER I.: Tápanyagtáblázat. Budapest: Medicina Könyvkiadó Rt., 2005.

[7] BIRÓ G., BIRÓ GY.: Élelmiszer-biztonság, táplálkozás-egészségügy. Budapest: Agroinform Kiadó Kft., 2000.

[8] BIRÓ GY., LINDNER K.: Tápanyagtáblázat. Budapest: Medicina Kiadó, 1998.

[9] MOLNÁR J., AMBRUS B., ZSÉDELY E.: Minőségi élelmiszerek fogyasztásának szerepe az egészség megőrzésében. Élelmiszer Tudomány Technológia, 684 (2014), 13-17.

[10] HUNTER-MOLNÁR R., KOVÁCS A. J., LAKATOS E.: Analysis of properties of drying apple chips. In. DALMADI I., ENGELHARDT T., BOGÓ-TÓTH ZS., BARANYAI L., BÚS-PAP J., MOHÁCSI-FARKAS Cs. (Eds.): Food Science Conference 2013 - With research for the success of Darányi Program: Book of proceedings. 328-331. Budapest: Budapesti Corvinus Egyetem Élelmiszertudományi Kar, 2013.

[11] KOVÁCS F.: Állati eredetű élelmiszer-előállítás élelmiszerbiztonság-életminőség. Magyar Tudomány, 9 (2002), 1141-1146.

[12] DUBLECZ K.: Állati termékek táplálkozás-élettani szerepe. Veszprém: Pannon Egyetem, 2011. (Tanulmány) 